\title{
Painful erections while being treated for OCD
}

Alan L. Schneider, MD, DFAPA, DABAM

\section{How would you handle this case?}

Answer the challenge questions at MDedge.com/ psychiatry and see how your colleagues responded

\section{$f$}

Discuss this article at www.facebook.com/ MDedgePsychiatry
While being treated for OCD, Mr. G, age 27, experiences

recurrent painful erections that last for hours and ejaculatory delay. What could be causing his symptoms?

\section{CASE Prolonged, painful erections}

Mr. G, age 27, who has a history of obsessivecompulsive disorder (OCD), presents to his internist's office with complaints of "masturbating several times a day" and having ejaculatory delay of up to 50 minutes with intercourse. The frequent masturbation was an attempt to "cure" the ejaculatory delay. In addition, Mr. $G$ reports that for the past 5 nights, he has awoke every 3 hours with a painful erection that lasted 1.5 to 2.5 hours, after which he would fall asleep, only to wake once again to the same phenomenon.

Mr. G's symptoms began 3 weeks ago after his psychiatrist adjusted the dose of his medication for OCD. Mr. G had been receiving fluoxetine, $10 \mathrm{mg} / \mathrm{d}$, for the past 3 years to manage his OCD, without improvement. During a recent consultation, his psychiatrist increased the dose to $20 \mathrm{mg} / \mathrm{d}$, with the expectation that further dose increases might be necessary to treat his OCD.

\section{HISTORY Concurrent GAD}

Mr. G is single and in a monogamous heterosexual relationship. Three weeks earlier, when he was examined by his psychiatrist, Mr. G's Yale-Brown Obsessive Compulsive Scale score was 28 and his Beck Anxiety Inventory score was 24. Based on these scores, the psychiatrist concluded Mr. G had concurrent generalized anxiety disorder (GAD).

\section{EVALUATION Workup is normal}

On presentation to his internist's office, Mr. G's laboratory values are all within normal range, including a chemistry panel, complete blood count with differential, and electrocardiogram. A human immunodeficiency virus test is negative. His internist instructs Mr. G to return to his psychiatrist.

\section{Mr. G's presentation most closely resembles} which of the following?

a) problematic nocturnal tumescence

b) potential surreptitious heroin use

c) priapism

d) serotonergic-based anorgasmia

\section{TREATMENT Dose adjustment}

Based on Mr. G's description of painful and persistent erections in the absence of

Dr. Schneider practices psychiatry, addiction medicine, and geriatric psychiatry in Sherman Oaks and Corona del Mar, California. He is the Western Regional Medical Director for Aetna Behavioral Health, and is Clinical Assistant Professor, Department of Psychiatry, USC Keck School of Medicine, Los Angeles, California.

Disclosure

The author reports no financial relationships with any companies whose products are mentioned in this article, or with manufacturers of competing products.

doi: $10.12788 /$ cp.0056 
sexual stimulation or arousal, and because these episodes have occurred 5 consecutive nights, the psychiatrist makes a provisional diagnosis of stuttering priapism and reduces the fluoxetine dose from 20 to $10 \mathrm{mg} / \mathrm{d}$.

\section{The author's observations}

Priapism is classically defined as a persistent, unwanted penile or clitoral engorgement in the absence of sexual desire/arousal or stimulation. It can last for up to 4 to 6 hours $^{1}$ or it can take a so-called "stuttering form" characterized by brief, recurrent, self-limited episodes. Priapism is a urologic emergency resulting in erectile dysfunction in 30\% to $90 \%$ of patients. It is multifactorial and can be characterized as low-flow (occlusive) or high-flow (nonischemic). Most priapism is primary or idiopathic in nature; the incidence is 1.5 per 100,000 individuals (primarily men), with bimodal peaks, and it can occur in all age groups. ${ }^{2}$ Secondary priapism can occur from many causes (Table).

\section{Mechanism is unclear}

The molecular mechanism of priapism is not completely understood. Normally, nitrous oxide mediates penile erection. However, cyclic guanosine monophosphate (cGMP) acts at several levels to create smooth muscle reaction, leading to either penile tumescence or, in some cases, priapism. Stuttering or intermittent ischemic priapism is thought to be a downregulation of phosphodiesterase type 5, causing excess cGMP with subsequent smooth muscle relaxation in the penis. ${ }^{3}$

\section{Drug-induced priapism}

Drug-induced priapism is commonly believed to be associated with alpha- 1 adrenergic receptor blockade. ${ }^{4}$ This also results in dizziness and orthostatic hypotension. ${ }^{5}$ Trazodone is commonly associated with the development of secondary priapism; however, in the last 30 years, multiple case reports have demonstrated that a variety of

\section{Table}

\section{Causes of secondary priapism}

\begin{tabular}{l} 
Hematologic: Sickle cell disease, \\
thalassemia, multiple myeloma, thrombotic \\
thrombocytopenic purpura \\
\hline Spinal shock or pelvic/penile trauma \\
\hline Malignancy or metastatic cancer \\
\hline $\begin{array}{l}\text { latrogenically induced from intracavernous } \\
\text { injection }\end{array}$ \\
\hline Infarction (malaria) \\
\hline Metabolic disease: Diabetes mellitus, gout, \\
hemodialysis, amyloidosis \\
\hline $\begin{array}{l}\text { Medications: Phosphodiesterase type } 5 \\
\text { inhibitors, antidepressants, antipyretics, alpha } \\
\text { blockers, stimulants, anticoagulants, cocaine, } \\
\text { antihypertensives }\end{array}$
\end{tabular}

psychoactive agents have been associated with low-flow priapism. ${ }^{6}$ Most case reports have focused on new-onset priapism associated with the introduction of a new medication. Based on a recent informal search of Medline, since 1989, there have been $>36$ case reports of priapism associated with psychotropic use. Stuttering priapism is less frequently discussed in the literature. ${ }^{7}$

Ischemic priapism accounts for $95 \%$ of all reports. It can be associated with medication use or hematologic disorders, or it can be triggered by sexual activity. Often, patients who experience an episode will abstain from sexual contact.

The etiology of stuttering priapism is less clear. Episodes of stuttering priapism often occur during sleep and can resolve spontaneously. ${ }^{8}$ They are a form of ischemic priapism and are seen in patients with sickle cell anemia. It is not known how many patients with stuttering priapism will convert to the nonremitting form, which may require chemical or surgical intervention. ${ }^{9}$ Stuttering priapism may go unreported and perhaps may be overlooked by patients based on its frequency and intensity.

The activating selective serotonin reuptake inhibitor fluoxetine has a long half-life and is a potent inhibitor of the cytochrome

\section{Clinical Point \\ Drug-induced priapism is commonly associated with alpha-1 adrenergic receptor blockade}




\section{Clinical Point}

For Mr. G, it is possible that fluoxetine's weak norepinephrine reuptake inhibition resulted in an intermittent priapism effect
P450 2D6 isoenzyme system. It inhibits serotonin transporter proteins. It is also a weak norepinephrine reuptake inhibitor, an effect that increases with increasing doses of the medication. Its 5HT2C antagonism is proposed as the mechanism of its activating properties. ${ }^{10}$ In Mr. G's case, it is possible that fluoxetine's weak norepinephrine reuptake inhibition resulted in an intermittent priapism effect mediated through the pathways described above.

\section{OUTCOME Symptoms resolve}

Approximately 1 week after Mr. G's fluoxetine dose is reduced, his symptoms of priapism abated. The fluoxetine is discontinued and his ejaculatory delay resolves. Mr. G is started on fluvoxamine, $150 \mathrm{mg} / \mathrm{d}$, which results in a significant decrease of both GAD and OCD symptoms with no notable ejaculatory delay, and no recurrence of priapism.

\section{The author's observations}

Mr. G's case and other case reports suggest that psychiatrists should caution patients who are prescribed antidepressants or antipsychotics that stuttering priapism is a possible adverse effect. ${ }^{11}$ As seen in Mr. G's case, fluoxetine (when used chronically) can moderate vascular responses at the pre- and post-synaptic adrenergic receptor. ${ }^{11}$ Priapism induced by a psychotropic medication will not necessarily lead to a longer-term, unremitting priapism, but it can be dramatic, frightening, and lead to noncompliance. Along with obtaining a standard history that includes asking

\section{Related Resource}

- Thippaiah SM, Nagaraja S, Birur B, et al. Successful management of psychotropics induced stuttering priapism with pseudoephedrine in a patient with schizophrenia. Psychopharmacol Bull. 2018;48(2):29-33.

\section{Drug Brand Names}

Fluoxetine • Prozac

Fluvoxamine - Luvox

patients about prior adverse medication events, psychiatrists also should ask their patients if they have experienced any instances of transient priapism that may require further evaluation.

\section{References}

1. Kadioglu A, Sanli O, Celtik M, et al. Practical management of patients with priapism. EAU-EBU Update Series. 2006;4(4):150-160.

2. Eland IA, van der Lei J, Stricker BHC. Incidence of priapism in the general population. Urology. 2001;57(5):970-972.

3. Halls JE, Patel DV, Walkden M, et al. Priapism: pathophysiology and the role of the radiologist. Br J Radiol. 2012;85(Spec Iss 1):S79-S85.

4. Wang CS, Kao WT, Chen CD, et al. Priapism associated with typical and atypical antipsychotic medications. Int Clinical Psychopharmacology. 2006;21(4):245-248.

5. Khan Q, Tucker P, Lokhande A. Priapism: what cause: mental illness, psychotropic medications or polysubstance abuse? J Okla State Med Assoc. 2016;109(11):515-517.

6. Dent LA, Brown WC, Murney JD. Citalopram-induced priapism. Pharmacotherapy. 2002;22(4):538-541.

7. Wilkening GL, Kucherer SA, Douaihy AB. Priapism and renal colic in a patient treated with duloxetine. Mental Health Clinician. 2016;6(4):197-200.

8. Morrison BF, Burnett AL. Stuttering priapism: insight into its pathogenesis and management. Curr Urol Rep. 2012;13(4):268-276

9. Burnett AL, Bivalacqua TJ. Priapism: current principles and practice. Urol Clin North Am. 2007;34(4):631-642.

10. Stahl SM. Stahl's essential psychopharmacology: neuroscientific basis and practical applications. 4th ed. Cambridge, United Kingdom: Cambridge University Press; 2013.

11. Pereira CA, Rodrigues FL, Ruginsk SG, et al. Chronic treatment with fluoxetine modulates vascular adrenergic responses by inhibition of pre- and post-synaptic mechanisms. Eu J Pharmacol. 2017;800:70-80.

\section{Bottom Line}

Any psychotropic medication that has the capacity to act on alpha adrenergic receptors can cause priapism. Ask patients if they have had any unusual erections/ clitoral engorgement while taking any psychotropic medications, because many patients will be hesitant to volunteer such information. 